IZA DP No. 7073

Immigration and Trade Creation for the U.S.:

The Role of Immigrant Occupation

Kusum Mundra

December 2012 


\title{
Immigration and Trade Creation for the U.S.: The Role of Immigrant Occupation
}

\author{
Kusum Mundra \\ Rutgers University \\ and IZA
}

\section{Discussion Paper No. 7073 \\ December 2012}

\author{
IZA \\ P.O. Box 7240 \\ 53072 Bonn \\ Germany \\ Phone: +49-228-3894-0 \\ Fax: +49-228-3894-180 \\ E-mail: iza@iza.org
}

\begin{abstract}
Any opinions expressed here are those of the author(s) and not those of IZA. Research published in this series may include views on policy, but the institute itself takes no institutional policy positions. The IZA research network is committed to the IZA Guiding Principles of Research Integrity.

The Institute for the Study of Labor (IZA) in Bonn is a local and virtual international research center and a place of communication between science, politics and business. IZA is an independent nonprofit organization supported by Deutsche Post Foundation. The center is associated with the University of Bonn and offers a stimulating research environment through its international network, workshops and conferences, data service, project support, research visits and doctoral program. IZA engages in (i) original and internationally competitive research in all fields of labor economics, (ii) development of policy concepts, and (iii) dissemination of research results and concepts to the interested public.
\end{abstract}

IZA Discussion Papers often represent preliminary work and are circulated to encourage discussion. Citation of such a paper should account for its provisional character. A revised version may be available directly from the author. 
IZA Discussion Paper No. 7073

December 2012

\section{ABSTRACT \\ Immigration and Trade Creation for the U.S.: The Role of Immigrant Occupation}

This paper highlights that the immigrants' effect on trade is not identical across all types of immigrants but it varies with the immigrants' occupation. Using a sample of 63 U.S. trading partners which are also big immigrant sending countries over the years 1991-2000, this paper finds that the immigrant trade elasticity for the no occupation group is similar in magnitude to the immigrant effect on trade estimated in the literature. However, this does not capture the full extent of the effect of immigrant network on trade. The share of professional immigrants in comparison to immigrants with no occupation significantly increases the trade elasticity for Rauch's referenced price and differentiated commodities and this effect is strongest for the differentiated goods. This paper establishes that immigrants' occupation is an important indicator of the quality and effectiveness of immigrants' network in trade creation with the home country.

JEL Classification: F22, F11, J10, J61

Keywords: immigrant occupation, immigrant networks, bilateral trade, U.S.

Corresponding author:

Kusum Mundra

Department of Economics

Rutgers University

Newark, NJ 07102

USA

E-mail: kmundra@andromeda.rutgers.edu 


\section{Introduction}

The area of international trade and the immigrant Diaspora has recently seen many studies exploring the role of immigrant networks on the bilateral trade with the immigrants' home country. Beginning with the work of Gould (1995) there have been many research papers establishing the pro trade effect of immigration on trade for different immigrant receiving countries and both for exports and imports,. Trefler (1995) has found a strong evidence for coethnic and social networks in explaining the missing trade links and Grief (1993) and Rauch and Casella (1998) have shown that business and social networks help in reducing informational trade barriers. Immigrant population living in a country provides the social and co-ethnic networks that facilitate trade with their home country by removing some informal trade barriers and lowering transactions cost to trade. The literature has found strong evidence that the immigrant based networks have a positive effect on bilateral trade for the U.S. (Gould 1994; Dunlevy and Hutchinson 1999; Dunlevy 2004; Rauch 1999; Herander and Saavedra 2005; Bandyopadhyay et al., 2008), for Canada (Head and Reis 1998) and for UK (Girma and Yu 2002) to name a few. It is also well known that the effect of immigrants on trade varies with the type of good. Rauch and Trindade (2002) show that the ethnic Chinese populations increase bilateral trade between countries more for differentiated goods than for the homogeneous goods. ${ }^{1}$

The literature exploring the effect of immigrant networks on trade, however, so far, has focused on the size of the immigrant networks and not on the quality of the immigrant network. In addition to the effect of the immigrant network size, this paper looks into the effect of the immigrant network quality on trade by examining the role of the immigrants' occupation on trade with their home countries. This paper proposes that by simply looking at the size of the immigrant stock, we might be underestimating the effect of immigrant networks on trade and the distribution of the immigrant network across immigrant occupation may have a significant effect on trade flows. This paper estimates the effect of immigrants' occupation on the U.S. bilateral trade flows with their home country using a sample of 63 trading partners over the period 1991 - 2000. During the period 1981-1990 total immigration to the U.S. was around 7.3 million and it increased to more than 9 million during $1991-2000$, with almost $70 \%$ of the immigrants for the year 2000 coming from Latin America. ${ }^{2}$ In addition, we observe that the U. S. international trade with the immigrants' home country is on the rise. The value of U. S. imports for the period 1987 - 1995 with

\footnotetext{
1 According to Rauch (1999) goods are classified into organized exchange if they are listed on the organized exchange, whereas they are classified as reference priced if their prices are quoted in trade bulletins. Differentiated goods are not homogenous goods and cannot be listed on any organized exchange or have a reference priced printed in trade bulletins.

${ }^{2}$ From the U.S. Department of Homeland Security (formerly called the Immigration and Naturalization Service, INS).
} 
North America have increased by 110\%; with Pacific Rim, by 125\%; and with Latin American regions, by 100\%. Similarly, U. S. exports with North America went up by 95\%; with Pacific Rim, by 65\%; and with Latin America, by $46 \%{ }^{3}$

In addition to the size of the immigrant stock Gould (1995) controlled for the ratio of skilled to unskilled migrants. Though, contrary to the immigrant home link effect his findings show that immigrant skilled and unskilled ratio has a negative effect on both exports and imports, other than on the producer imports. Gould argues that skilled immigrants increase trade but they simultaneously create industries in the host country that might potentially lead to import substitution. However, this does not explain his finding of a negative effect of skilled to unskilled immigrant ratio on exports. Head and Ries (1998) have examined the role of the immigrant population on trade for Canada across different entry class of immigrants. They find that the trade creating effect of the entrepreneur group of immigrants on trade is weaker than the group of family immigrants and is strong only when compared to the refugees. They argue that this is possibly due to the point system followed by Canada and that the independent classes of immigrants because of their capital or self employed status (many maybe artists) receive bonus points and may not necessarily be carrying enough market contacts or home market information facilitating trade. In Canada, moreover, entrepreneurs were discouraged from importing goods from their home country. However, U.S. does not follow any point system and in spite of a big family reunification and amnesty component to its immigration policy, immigration to the U.S. is primarily driven by individuals’ occupation and skills. Also, there have been many policies promoting self employment among the immigrants to encourage their assimilation into the U.S. economy and society.

Contrary to the earlier findings in the literature this paper finds that the professional and executive immigrants have a significant effect on trade creation between the U.S. and their home country compared to the immigrants with no occupation. This holds for both exports and imports and across Rauch's reference priced and differentiated goods. The immigrant trade elasticity for the no occupation group, which is the reference group, ranges between $0.2-0.8$ depending on the commodity and the trade type. This is similar to the earlier findings in the literature. ${ }^{4}$ This paper finds that the professionals from a country j further increase this trade elasticity for the

\footnotetext{
${ }^{3}$ Author's calculation from the trade data in International Economic Review, United States International Trade Commission, Washington DC.

${ }^{4}$ Table A1 in the Appendix gives the main findings in the literature on the immigrant trade elasticity for the U.S. and Canada where the focus is only on the total immigrant size,
} 
U.S. by 0.002 to 0.006 times the share of the professional immigrants from home country j depending on the commodity and whether it is export or import. The highest effect is for the Rauch's differentiated imports.

This paper makes several contributions to the literature. First, it highlights that the pro-trade effect of immigrants on trade varies across the immigrant's occupation and the type of goods. By examining only the effect of immigrant network size we are potentially underestimating the immigrant network effect on trade creation. The key hypothesis of this paper is that in addition to the size of the immigrant network the distribution of the immigrant network across different occupations in the U.S. has a significant effect on trade flows. Second, this paper examines the above hypothesis for both total exports and imports as well as across different commodity types, particularly Rauch's referenced price and differentiated group of commodities. The third contribution of this paper is that it takes into account the possible endogeniety of the immigrant network. We use the historical immigrant networks and whether the home country allows a dual citizenship as our instruments to identify the effect of immigrant network on trade flows. The literature has so far neglected to take into account the possibility that the immigrant stock and the trade flows might be endogenous. ${ }^{5}$ Finally, this paper uses new data on U.S. immigrant stock across occupation groups for the U.S. over 1991 - 2000 calculated from 2000 census data and the annual data on the legal permanent residents across occupation from the the U.S. Department of Homeland. ${ }^{6}$

The plan of the paper is as follows. Section II puts forth arguments supporting the principal hypothesis of this paper that the effectiveness of the immigrant based network in stimulating bilateral trade is dependent on the immigrants' occupation in their host country. Section III discusses the data and presents the empirical model. In Section IV we discuss our results and we conclude in Section V.

\section{Immigration and Trade Creation - Role of Immigrant Occupation}

Immigrants increase trade between the U. S. and their home country by providing home country information in the U. S. This information reduces informal trade barriers and stimulates trade between the U. S. and the immigrant's home country; immigrants in the U. S. provide co ethnic networks and immigrant enclaves that help in trade. These ethnic and social networks provide strong pull for more immigration and helps in building a pool of home country information in the U. S. In the literature it is well documented that the immigrant information has two distinct effects: matching buyers and sellers and enforcement of trading contacts.

\footnotetext{
${ }^{5}$ In recent papers Peri and Requena (2012) and Vezina (2011) uses IV estimation to take account of the endogeneity of the immigrants while examining the effect of immigrant networks on Spain's exports and Swiss exports, respectively.

${ }^{6}$ Annual data on immigrant stock across occupations and countries did not exist before. This dataset is available from the author upon request.
} 
The first effect of matching between traders is an important immigrant link on trade, Dunlevy (2004) calls this information bridge. Immigrants have information on traders and the type of goods available in the U. S. and their home countries; they help in promoting international trade between U. S. and their home country. For instance, Korean exports substantially increased since the early 1970s when a massive influx of Koreans to the U. S. began. By virtue of the advantages associated with their language and ethnic background, many Korean immigrants have established business' importing merchandise from Korea (Min 1990). In addition to the matching of buyers and sellers, immigrants bring information on how business is conducted in their home country; thereby helping in the enforcement for trading contacts Dunlevy (2004) calls this the cultural bridge. As pointed out by Grief (1993), coethnic networks promote trade by preventing violation of trading contacts particularly when the legal environments are not well developed.

The literature, however, has not addressed the issue that all immigrants are not at an equal footing on how they generate trade with their home country. The social capital and coethnic networks created by the immigrants in the U.S. will vary according to their occupation and so will their information affect generating trade. There is increasing evidence on the important role played by Indian business and social networking organizations (such as TiE, The Indus Entrepreneurs) in facilitating Indian immigrant entrepreneurs, particularly in the IT sector in the U.S. An Indian immigrant who is a homemaker or a student might not have the same social capital and will not be participating in the TiE's social and professional networking and entrepreneurship meetings and hence will have a lower information effect on trade than the Indian immigrant who is an engineer or a CEO. Moreover, the size and quality of the immigrants' coethnic network in the U.S. will vary according to their occupation; engineers will tend to network more with other engineers and professionals from India. There will be more exchange of ideas and innovation across managerial and professional immigrant groups and this will have a greater potential in lowering informal trade barriers and increasing trade with their home countries. In this paper we propose that what is important for trade building is the size and the quality of the immigrants' network and the individual migrants’ occupation is an important indicator of the quality and determinant of the effectiveness of immigrants' network in trade creation with the home-country, both via externality of the foreign market information and personal business contacts.

There is also increasing evidence of the important role played by export intermediaries in stimulating U.S. exports, particularly for the small exporters who rely on third parties more than the big multinationals that have in- 
house export departments (Becker and Porter 1983; Peng and llinitch 1998). To increase competitiveness of the U.S. exports, the export intermediaries have to play an important role in mitigating the trade barriers for the U.S. firms (U.S. Small Business Administration 1989, 1991). Peng (1998) using a large mail survey finds that more than $50 \%$ of the export intermediaries in the U.S. specialize in the Asian and Latin American region, which are big trading partners for the U.S. as well as the major new immigrant sending countries. Peng also finds that over $90 \%$ of the intermediaries in his sample had a in-house foreign language specialist and close to $40 \%$ of the personnel who worked in these intermediaries were immigrants, which made these export intermediaries expert in foreign regions and helped them to stimulate U.S. exports. Light et al.(2002) have also highlighted the role of immigrants as middlemen in trade promotion; however, using the census data they find that entrepreneurship rates significantly increase U.S. exports but not U.S. imports.

Immigrant's occupation will explain to what extent immigrants are able to use their co-ethnic networks and personal information for trading. Our first hypothesis is that not all categories of immigrants will have a similar protrade effect on trade, particularly in building trading contacts and lowering transactions cost to trade, and the most significant and positive effect will be for the professional and higher skilled immigrants. For instance, managers, professionals, and executives will have a more significant effect on trade promotion with their home country than homemakers and retired personnel and this effect will be present both for the U. S. exports and U. S. imports. Trading information on the homogenous goods is easily available across countries and immigrant information is less important compared to the differentiated goods, where the informal trade barriers are most severe and hence a priori the immigrant effect on trade should be strongest for the differentiated products. Similar to immigrants in the professional and executive group, immigrants in sales and services might also be facilitating trade between the U.S. and the home country through trade negotiations and information effect, particularly in the referenced price goods, where the arbitrage possibility exists for a profitable trading between the home country and the U.S.

For imports, a priori, all the groups might have a positive effect through their demand for goods from their home country, though possibly in different magnitudes. In addition, immigrants with rising income in the U.S. may be demanding less of the goods from their home country - some possibility of an assimilation effect. It is worth discussing, as one might wonder, whether immigrants’ income maybe a proxy for their occupation, but not entirely. Even if the construction and an engineer might earn same level of income, an engineer has an immigrant network 
that is more conducive to trade promotion than the construction workers. In sum, the effect of immigrants on trade across different occupations will vary with the trade type and the commodity type.

\section{Empirical Model and Data Description}

\section{A. Gravity Specification}

The empirical model is based on the 'gravity framework,' where the trade between the U. S. and its trading partners, who are also immigrant-sending countries, is explained by different economic factors in the U. S. and the home countries. We begin our specification with the basic gravity where the trade $\left(F_{i j}\right)$ is proportional to the product of GNP or GDP of the two countries $\left(Y_{i}\right.$ and $Y_{j}$ ) and inverse to distance between the two countries, $D_{i j}$ Frankel (1997):

$$
F_{i j}=\frac{Y_{i} Y_{j}}{D_{i j X_{i j}}}
$$

To this multiplicative Gravity model we add product of per capita GNP, which takes into account the diverse stages of development of the two trading partners (Frankel 1995, Rauch 1999). The vector $X_{i j}$ includes factors that assist or hinder trade through trading cost. In addition to the total income capturing the size of the economy and relative income accounting for the similarity between the U. S. and other countries, we include along the lines of Frankel, whether the U.S. and its trading partners are neighbors and whether both are English speaking countries. Trade flows between U. S. and its bordering countries, Canada and Mexico, is enhanced by a common border. The gravity model in (1) extends to

$$
F_{U S j}=\left(G N P_{U S} G N P_{j}\right)^{\alpha}\left(P G N P_{U S} P G N P_{j}\right)^{\beta}(\text { Distance })_{U S j}^{-\gamma} e^{-X_{U S j}}
$$

In equation (2) , $F_{U S j}$ are U. S. exports to the immigrants' home country j in the export model and U. S. imports from the immigrants' home country $\mathrm{j}$ in the import model. $G N P_{U S} G N P_{j}$ is the product of the U.S. and the home country GNP; $P G N P_{U S} P G N P_{j}$ is the product of the U.S. per capita GNP and the home country per capita GNP, Distance $_{U S j}$ is the bilateral distance between the home country and the U.S. and $X_{U S j}=\left(\right.$ Adjacency $\left._{U S j}, \ln (\text { IMMSTOCK })_{U S j}\right)$. Adjacency is a dummy variable which takes the value 1 if the U.S and the home country are adjacent to each other (this captures the dummy for Canada and Mexico) and $\ln (\text { IMMSTOCK })_{U S j}$ is the immigrant stock in the U.S. and measures the size of the immigrant network from country $j$ in the U.S. The econometric model after taking log on both sides of (2) and over time $t$ is 
$\ln F_{U S j t}=\rho+\alpha \ln \left(G N P_{U S} G N P_{j}\right)_{t}+\beta \ln \left(P G N P_{U S} P G N P_{j}\right)_{t}+\gamma \ln (\text { Distance })_{U S j}+\mu$ Adjacency $_{U S j}+$

$\delta \ln (I M M S T O C K)_{U S j t}+\varepsilon_{U S j t}$

where $\delta$ is the immigrant elasticity of trade and $\varepsilon_{U S j}$ is the usual iid error term. .

We categorize immigrant stock in the U.S. based on the immigrant occupations. Following 2000 Census we categorize immigrants into the following four categories of occupation: management, professional and related occupation (Professional); service, sales and office administration (Services); construction, precision workers, laborers and farming (Laborers); No occupation (includes retired persons, students, and home-makers). Our second model extends the model in (3) to vary the immigrant elasticity with the share of the population in different occupation categories as follows:

$\ln F_{U S j t}=\rho+\alpha \ln \left(G N P_{U S} G N P_{j}\right)_{t}+\beta \ln \left(P G N P_{U S} P G N P_{j}\right)_{t}+\gamma \ln (\text { Distance })_{U S j}+\mu$ Adjacency ${ }_{U S j}+$

$\delta \ln (I M M S T O C K)_{U S j t}+\sum_{k=1}^{3} \delta_{k} \ln (I M M S T O C K)_{U S j t} * S_{U S j k t}+\varepsilon_{U S j t}$

Where $S_{U S j k}$ is the share of the immigrants from home country $\mathrm{j}$ in the k-th occupation where $k$ goes from 1 to 3 and no occupation is the reference category. The immigrant elasticity in equation (4) varies with the share of the immigrant population in the professional, services and labor occupation.

\section{B. Data}

Our sample consists of 62 countries over the time period $1991-2000 .^{7}$ The U.S. export and import data is obtained from the extension of the World Trade Database of Statistics Canada, which is a part of the NBER World Trade Database by Feenstra et al. (2005). Nominal GNP and population are from the Penn World tables 6.1 (Heston et al. 2006). ${ }^{8}$ Annual data on immigrants across occupation is from the Immigration Statistical Yearbook from the Department of the Homeland Security and the data on distance and English language is obtained from Frankel. ${ }^{9}$ The sample summary statistics across countries is given in the Appendix Table A4.

\footnotetext{
${ }^{7}$ We add El Salvador and Nicaragua (due to significant immigration from these two countries to the U.S.) and remove Yugoslavia (due to scanty data) from the sample of countries used in Frankel (1997).

${ }^{8}$ The trade data is downloaded from the Center for International Data at the UC Davis (http://cid.econ.ucdavis.edu.) and the website for the Penn World Tables is http://pwt.econ.upenn.edu

${ }^{9}$ Distance is in Kilometers and for El Salvador and Nicaragua has been updated from "Direct-Line Distances”, International Edition, Gary L. Fitzpatrick and Marilyn J. Modlin, Scarecrow Press, Inc. Metuchen NJ and London 1986.
} 


\section{The Immigrant Network Variable: across Occupation}

Immigrant stock gives a better proxy for the immigrants’ network in the U.S. than the immigrant flow data and the only source for immigrant stock data in the U.S. is the U.S census every ten years. In order to calculate the annual immigrant stock across different occupation from the 62 origin countries over 1991 - 2000 we begin with the 2000 Census stock of foreign born non-citizen across different occupation groups and then use the annual data on legal permanent residents from the Homeland Security for every year to calculate the annual stock of immigrants across different occupation groups as follows:

$$
\text { Stock of } \operatorname{Imm}_{j k t-1}=\text { Stock of } \operatorname{Imm}_{j k t}-\operatorname{Imm}_{j k t}
$$

where Stock of Imm is the stock of immigrants from country $j$ in occupation $k$ in year $\mathrm{t}$ and Imm is the annual flow of immigrants from country $\mathrm{j}$ in occupation $k$ in the year t. The annual flow of immigrants for different country across occupation is the annual data on legal permanent residents from different countries. ${ }^{10}$ This estimate of the immigrant stock is not exact and there is a possibility that we might be overestimating the stock of immigrants or underestimating the stock. Overestimation is possible because the census 2000 data includes all foreign born noncitizens in the U.S. from a country $\mathrm{j}$ whereas the annual permanent immigration flow data includes everybody who became a legal permanent resident in that particular year. However, there is also a possibility of underestimation because some legal permanent residents from the early 1990s might already be citizen in the year 2000 and so not included in the 2000 Census stock of foreign non-citizen. Due to lack of data availability this methodology and these particular data sources have been used to calculate the immigrant stock at the national level as well as the state level for the U.S. (Dunlevy 2004; Herander and Saavedra 2005). Head and Reis (1998) also uses this methodology to calculate the immigrant stock for Canada, though because of better data availability on immigrant stock they were able to improve the annual immigrant stock by adjusting for annual attrition rate ${ }^{11}$ Since we are measuring the stock backward for our sample potentially our stock measure suffers less from the mortality and the emigration of the immigrants.

If immigrant occupation played a role in the trading opportunities one would expect that higher the proportion of executive and professional immigrants from a country the higher will be their immigrant network

\footnotetext{
${ }^{10}$ The Homeland Security collects this data from the Green card form the year the individual becomes a legal permanent resident, though they might be in the U. S. from many years or they might have arrived to the U. S. that year as a Legal Permanent Resident.

${ }^{11}$ Head and Reis (1998.) had a sample from 1980 - 1992 and data on immigrant population for 1981, 1986, and 1990 enabling a better measure of immigrant attrition.
} 
effect. A CEO and an engineer will be better able to mitigate information barriers and match buyers and sellers with their home country and are in a better position to facilitate trade compared to immigrants in production or in construction or in farming. The immigrants who are in the executive and professional occupation will have a stronger immigrant network with fellow professionals from their country and will also be in a better position to provide stronger trade stimulus between the U.S. and their home country than other group of immigrants. They will be using the home country knowledge and information in entrepreneurial activities opening new channels of trade with their home country; involved in a more efficient search of goods and buyers or sellers in the home country and better trade negotiations. On the other hand if the immigrant is a homemaker or a retired person or is a construction worker or is in farming they might not have the kind of immigrant networks one needs to increase trade via the information effect. We will expect that immigrants in the management and professional occupation will have the most significant effect on trade compared to any other group. It is worth mentioning that a priori immigrants in services and sales may also be promoting trade with their home country using their foreign market information and personal business contacts, more than the immigrants in the laborer occupation and in the no occupation categories.

Table 1 displays the average trade flows, size of the immigrant network, and the distribution of the immigrant network across different occupations for the top 28 U.S. trading partners. Figure 1 show the average trends in the total trade flows and immigrant stock, and Figure 2 the average proportion of immigrants in the professional executive, and management profession over the period 1991 - 2000. We see that for more than half of the countries out of the top 28 trading partners; have more than 25\% of their immigrants in the Management and Professional occupation. The general hypothesis proposed in this paper is that higher the professional and executive immigrants from a country, higher will be the bilateral trade of the U. S. with that country. But, there are some interesting exceptions, such as Mexico and Nigeria. Mexico is a big trading partner with the U.S. and has the highest immigrant stock, but only 5\% of the immigrant population from Mexico is in professional occupation. Clearly it is not the skilled immigrants that are significant factors behind the trade between Mexico and the U.S., but the history, geography and the trading blocs like NAFTA. Another interesting exception is Nigeria; $43 \%$ of the Nigerian immigrant stock of 90,790 consists of the professional and executive profession, however, Nigeria is not in the top 28 trading partner (see Table A2 in the Appendix for detail breakdown of immigrant network across occupations for all the countries) and the reason behind that may be the difference in the per capita income levels 
between Nigeria and the U.S., the geographical distance with the U.S. (see the country summary statistics Table A3 in the Appendix).

From Table A2 we see that the proportion of immigrants in the professional occupation for Taiwan is $43 \%$ whereas for Mexico it is only 5\%. On the other hand the proportion of immigrants in construction, production, laborers and farming from Mexico is 31\% whereas from Taiwan it is only $4 \%$. From Table 1 we further see that the for some countries the average professional and services share are close, such as for Germany, Hong Kong, South Korea whereas for Brazil 34\% are in services and sales and only 17\% are in the professional and executive class. For India, with the second largest immigrant network $28 \%$ are in the professional and executive management profession whereas only 7\% are in the laborer group, whereas for Mexico with the highest size of immigrant 31\% are in the laborers, forestry and farming occupation and only $5 \%$ are in the professional, management, and executive profession. ${ }^{12}$

\section{Rauch's Reference Priced and Differentiated Commodities}

To further examine the immigrant trade elasticity across occupation we classify commodities at the SITC 4 level into Rauch’s reference priced and differentiated goods using 4 digit SITC trade data. Internationally traded goods are classified as referenced price if their prices are quoted in trade bulletins and differentiated goods are not listed on any organized exchange or have a reference price printed in trade bulletins. . Immigrants’ networks will be most effective in trade creation through their home country information effect of matching buyers and sellers in differentiated goods. Though, the networks can also play an important role in matching buyers and sellers in the reference priced group and possibly increase trade with their home country. The models given in (3) and (4) are estimated for both the aggregate U.S. exports and imports as well as across Rauch’s reference priced, and differentiated goods. ${ }^{13}$

\footnotetext{
${ }^{12}$ There is a possibility that together with the immigrant stock the distribution of the immigrants across various occupation groups is endogenous. For instance, multinational corporations often responsible for increasing trade between the U.S. and the home country may send personnel to the U. S. from the home countries making the share of professionals endogenous to trade. Given the lack of data from various countries and the problem with weak instruments, which is particularly severe in the case of multiple endogenous variables, we tackle the endogeneity of the size of the immigrant stock in this paper (Bound et al. 1995; Stock et al. 2002). This problem might be less severe in my dataset because often these personnel are on a temporary visitor's visa or H1 (work visa) and are not included in the share of the legal permanent resident group data obtained from the Homeland Security.

${ }^{13}$ We use Rauch's Liberal aggregation. For details on the commodity groups and the liberal and conservative aggregation please see Rauch (1999) and Rauch and Trindale (2002).
} 
Our main thesis is that the immigrants in the professional and executive profession will have a significant trade creation effect compared to the no occupation group of immigrants and this effect will be particularly strong for the differentiated goods. Immigrants in services and sales, even if weaker than the management and CEO and the entrepreneur group, might also have an important effect on trade creation compared to the laborer group of immigrants. This effect might be stronger for the reference priced goods, where there is an arbitrage possibility between the U.S. and the home country products without the immigrants required to have entrepreneurial human capital. A priori all immigrants have a significant effect on imports and again stronger for the differentiated imports.

\section{E. Endogeniety of the Immigrant Network: Instrumental Variable Estimation}

In equation (3) the immigrant stock maybe endogenous possibly due to the omitted factors that simultaneously affect the trade flows and the immigrant population size. In order to address the potential endogeneity of immigrant stock we use instrumental variable methods in the estimation of equation (3) and equation (4) The current immigrant stock will be strongly determined by the historic stock and so we use the 1980 census to calculate the historic immigrant size (IMM 80) and a dummy measuring whether the home country allows a dual citizenship (Dual) as our instrument for the immigrant stock. ${ }^{14}$ Our instruments are all chosen based on their high correlation with our endogenous variables and are the standard instruments for migration and immigration. In addition to being significantly correlated to immigrant size the proposed instruments need to be uncorrelated to the error term in the main regressions. Our identifying assumption is that our instruments do not affect bilateral trade flows between the U.S. and the home country other than the immigrant stock. Given that we have more than one instrument, we test for the exogeneity of our instruments from an econometric standpoint using standard over-identification test and confirm their suitability in that regard. We test for heteroscedasticity and reject the null of "no heteroscedasticity" and therefore estimate equation (3) both by the OLS and by the instrumental variable GMM and correct the standard errors for heteroscedasticity. ${ }^{15}$ We also use an over-identification test that is robust in the presence of heteroscedasticity (Baum et al. 2003, 2007).

\footnotetext{
${ }^{14}$ The data on dual citizenship is obtained from the U.S. Office of Personal Management Investigation Service (2001), "Citizenship Laws of the World".

${ }^{15}$ Often Tobit models are estimated for trade flows, but in our sample there is no zero value trade for any year.
} 


\section{Estimation Results}

The specification in equation (3) and (4) is estimated for the aggregate and Rauch’s reference priced and differentiated products both using OLS and IV (2SLS) estimation methods. Before discussing our instrumental variable findings we check that the instruments being used are significantly correlated to immigrant stock size and that they can be considered exogenous from an econometric standpoint. First-stage results for equation (4) are displayed in Table A2 in the appendix. ${ }^{16}$ The two instruments we use in this specification are statistically significant at the 1 percent level and the over-identification test at the bottom of Tables A2 indicate that conditional on the other instrument being valid, our instruments can be considered exogenous.

The results from the estimation of model where immigrant elasticity of trade is not varying with occupation for the aggregate U.S. exports is given in Table $1 \mathrm{col}(3)$ and for imports in col (7). We discuss the results from the IV models only. Similar to the previous literature we find that the size of the immigrant stock has a strong positive effect on both U.S. exports and imports. Both the export and import elasticity is around 0.2. Col (4) and col (8) gives the results from equation (4) where we vary the immigrant trade elasticity with the different occupation groups. Since no occupation is the reference category the trade elasticity for this group is till 0.2 for aggregate exports. Though, the share of professionals is significant at $5 \%$ and share of immigrants in services at $10 \%$ in further increasing trade elasticity for the U.S. exports from 0.2 as follows: the immigrant trade elasticity of U.S. with the home country $\mathrm{j}$ is approximately $0.2+0.002$ (Share of professional from country $\mathrm{j}$ ) +0.001 (share of immigrants in services from country j). The distribution of immigrant population across the occupation category does not significantly influence aggregate U.S. imports.

The results for Rauch's reference priced goods are given in Table II. The estimation of equation (3), with only immigrant stock is given in cols (3) and (5) and we find that immigrant elasticity is still around 0.2 for exports but similar to previous findings is higher at 0.6 for imports and is significant at $1 \%$. However, when we allow the immigrant trade elasticity to vary with the occupation it is still around 0.2 for no occupation groups for the exports. Though, the effect of immigrant population on trade is now higher than when the immigrant trade elasticity does not vary with occupation. From col 4 we see that the share of professionals and immigrants in services have a positive effect on exports. For imports when we allow the immigrant elasticity to vary with occupation the trade elasticity jumps up to 0.7 for no occupation group (col 8) and the share of professional immigrants further increases this

\footnotetext{
${ }^{16}$ The first stage results for equation (3) holds and are available from the author upon request.
} 
elasticity. Contrary to aggregate trade flows the share of laborers lowers U.S. imports in Rauch's reference priced goods.

The results for Rauch's differentiated goods are given in Table III. The model with only trade elasticity of immigrant stock and no occupational effect is given in col (3) for exports and in col (7) for imports. We find that immigrant elasticity is still around 0.2 for exports but is higher at 0.8 for imports and both are significant at $1 \%$. This is similar to previous findings in the literature. When we allow the immigrant trade elasticity to vary with the occupation the immigrant trade elasticity for the no occupation reference group of immigrants is still 0.2 for exports and 0.8 for imports. Though, the overall effect of immigrant population on trade is now higher because the share of professionals have a positive effect on both exports and imports and is significant at 1\%, see Table II (col 4) and col (8) respectively. The immigrant trade elasticity for exports if we only include the occupation groups that are significant in explaining is $0.261+0.002$ (Share of professional from country $\mathrm{j}$ ) and for imports is $0.804+0.001$ (Share of professional from country $\mathrm{j}$ ).

Overall, similar to previous findings in the literature, we find that the immigrant trade elasticity is positive and significant for both exports and imports and is higher in magnitude for Rauch's differentiated imports. It is well known that the immigrant network effect and trade creation through various channels will be strongest for the differentiated goods. The contribution of this paper is that the immigrant trade elasticity significantly increases with the share of the professional immigrants for all types of goods for the U.S. and again is strongest for the Rauch's differentiated imports. Trade elasticity for the no occupation group, the reference group when we allow the elasticity to vary with the occupation share, is almost same to the immigrant stock elasticity when the occupation effect is not taken into account. What this implies is that by only taking into account the size of the immigrant network we are underestimating the effect of immigration on trade. The quality of immigrant network, here captured by immigrant's occupation plays a significant role in trade creation. In particular the share of professional immigrants greatly increases the immigration trade elasticity for the U.S. across all types of goods.

Immigrants in Services, as expected, also have a significant positive effect on the aggregate and Rauch’s reference priced exports. Immigrants in the services might be employed in the U.S. for the firms targeting U.S. exports to their home countries. We also find that the share of laborers lower the immigrant trade elasticity for the U.S. exports in the Rauch’s Reference Priced commodities. It is possible that laborers are potentially substituting home country imports with cheaper local substitutes for the referenced priced goods. 
What do the findings from this paper by varying immigrant stock trade elasticity with the occupational share tell in terms of magnitude? We illustrate this with the example of Mexico and India - two countries with very different distribution share of immigrants across various occupation groups.. Mexico has $5 \%$ of its immigrants in the professional occupation and 31\% are in the laborer group. Whereas, for India 5\% are laborers and $28 \%$ in the professional occupation. If there are no new additions to immigrant stock and all Mexican immigrants who are laborers become professionals the immigrant trade elasticity for aggregate exports at the mean will go up by 0.186 and for aggregate imports by 0.056 . For the Rauch's differentiated commodity the effect is lower for exports at 0.09 and significantly higher for imports at 0.155 . Since India already has a large share of immigrants in the professional occupation this exercise results in a lower increase in the trade elasticity. If $5 \%$ of the Indian share of laborers becomes professionals the aggregate export elasticity goes up by 0.03 and imports elasticity goes up by 0.09 . For Rauch's differentiated commodity the export elasticity goes up by 0.014 and for imports it goes up by 0.025 .

For the other gravity variables we find that the product of the log of GNP and per capita GNP are highly significant and have the expected sign. Higher is the distance between the U.S. and the home country lower is the trade, though we find that the adjacent dummy for Canada and Mexico is significant for the aggregate and Rauch's differentiated goods. If we drop from our sample the two neighboring countries for the U.S., Mexico and Canada, who are big trading partners as well as large immigrant sending countries, our findings are still robust. When we vary immigrant trade elasticity with occupation, English dummy loses its significance in explaining bilateral trade flows for the U.S. under IV estimation other than that for the referenced price exports.

\section{Conclusions}

This paper examines the role of the immigrant's occupation in generating trade with their home country via their coethnic immigrant network in the U.S. for the period 1991 - 2000. Immigrants are classified into four occupations and this paper finds that the proportion of professional immigrants are the most successful in stimulating trade with their home country compared to the no occupation group via the information effect and through potential networking with other fellow immigrants and natives. The immigrant trade elasticity for the no occupation group, which is the reference group, ranges between $0.2-0.8$ depending on the commodity and the trade type. This finding is similar to the earlier findings in the literature where the focus has mostly been on the size of the immigrant network. This paper finds that the professionals further increase this trade elasticity by 0.002 times 
the share of the professional immigrants from the home country for all types of exports. Whereas, this effect is 0.002 for Rauch's referenced priced imports and 0.006 times the share of the professionals for Rauch's differentiated imports.

This paper establishes that by only looking at the immigrant network size and not taking into account the immigrant heterogeneity in terms of the immigrant skill levels we are underestimating the effect of immigration on trade. By varying the immigrant trade elasticity across the occupation groups we find that the professional immigrants significantly increase immigrant trade elasticity for both the U.S. exports and imports for Rauch's Referenced priced and differentiated commodity types - where one will see the most significant effect of immigrant network on trade creation. Our results are robust across various products and models and even after taking into account the endogeneity of the immigrant network size. Clearly professional immigrants are in a better position to have a significantly stronger network effect and a greater effect on trade creation compared to the laborer group of immigrants. This paper establishes that immigrants' occupation is an important indicator of the quality and effectiveness of immigrants' network in trade creation with the home-country.

The results of the paper should not be interpreted as if all the immigrants to be allowed in a country have to be CEOs and entrepreneurs, because there are tremendous and well established positive impact on the growth of some sectors of the economy from unskilled immigration. This paper not only makes an important contribution in understanding the role of immigrants' occupation in bilateral trade across different commodity groups while taking into account the endogeneity of the immigrant network size, but also highlights the positive impact of high-skilled emigration on the exports and potentially economic growth and development of the country of origin.

\section{Acknowledgement:}

Special thanks to Jim Rauch for providing the SITC commodity classification for the Referenced Price and Differentiated commodity groups. 


\section{References}

Heston A., R. Summers and Bettina A. Penn World Table Version 6.2, Center for International Comparisons of Production, Income and Prices at the University of Pennsylvania, September, (2006).

Bandyopadhyay, S., C. Coughlin, and H. J. Wall, “Ethnic Networks and U.D. Exports,” Review of International Economics, 16(1), (2008), 199-213.

Barro, R. and Jong Wa Lee,“International Data on Educational Attainment: Updates and Implicatons” CID Working Paper No. 42, (2000).

Baum C. F., M. E. Schaffer, and S. Stillman. “Instrumental Variables and GMM: Estimation and Testing” Stata Journal 3, (2003), 1-31.

Baum C. F., M. E. Schaffer, and S. Stillman. "Enhanced Routines for Instrumental Variables/GMM Estimation and Testing” Boston College Economic Working paper No. 667, (2007).

Bound, J., Jaeger, D. A., and Baker, R., "Problems With Instrumental Variables Estimation When the Correlation Between the Instruments and the Endogenous Explanatory Variables Is Weak,” Journal of the American Statistical Association, 90, (1995), 443-450.

Combes, P. P., Lafourcade, M. and Mayer, T., “Can Business and Social Networks Explain the Border Effect Puzzle?” Working Paper, (2002).

Dunlevy, J. A. "Interpersonal Networks in International Trade: Evidence on the Role of Immigrants in Promoting Exports from the American States.” Review of Economics and Statistics , (2004).

Dunlevy, J. A., and W. K. Hutchinson, “The Impact of Immigration on American Import Trade in the Late Nineteenth and early Twentieth Century.” The Journal of Economic History 59(4), (1999), 1043-62.

Feenstra, R.C.,R.E. Lipsey, Deng Haiyan, Alyson C. Ma, Hengyong Mo, “World trade Flows: 1962-2000” NBER Working Paper Series, Working Paper 11040.

Frankel, J. A. Regional Trading Blocs in the World Economic System. Washington DC: Institute for International Economics, 1997.

Gould, D. M., “Immigrant Links to the Home Country: Empirical Implications for U. S. Bilateral Trade Flows,” Review of Economics and Statistics 76, (1994), 302-16.

Girma, S. and Z. Yu “The Link between Immigration and Trade: an Evidencefrom the United Kingdom,” Review of World Economics, 138(1), (2002), 115-130.

Greenwood, M. J. and J. M. McDowell “The Factor Market Consequences of U.S. Immigration,” Journal of Economic Literature 24(4), (1986), 1738-1772.

Grief, A. “Contract Enforceability and Economic Institutions in early Trade: The Maghribi Traders' Coalition,” American Economic Review 83.3 (1993): 525-548.

Hausman, J. A. “Specification Tests in Econometrics” Econometrica 46 (1978), 1251-1271.

Head, K., and J. Reis. “Immigration and Trade Creation: Econometric Evidence from Canada,” Canadian Journal of Economics 31.1 (1998): 47-62.

Helliwell, John F., How Much Do National Borders Matter? Washington D.C.: Brookings Institution, (1998). 
Herander Mark G. and Luz A. Saavedra, "Exports and the Structure of Immigrant-Based Networks: The Role of Geographical Proximity,” The Review of Economics and Statistics 87(2), (2005), 323-335.

Light, I., M. Zhou, and R. Kim. “Transnationalism and American Exports in an English-Speaking World,” International Migration Review, 36(3), (2002), 702-725.

McCallun, John. “National Borders Matter: Canada - U.S. Regional Trade Patterns,” American Economic Review 85, (1995), 615-623.

Min, P. G. “Korean Immigrants in Los Angeles.” in Institute of Social Science Research, ISSR Working Papers 2.2, University of California, Los Angeles, 1990.

Orrenius, P. M. and M. Zavodny, “Does Immigration Affect Wages? A look at Occupation-Level Evidence,” Labour Economics, (2007).

Peng, Mike W. "Behind the Success and Failure of U.S. Export Intermediaries- Transaction Agents, and Resources,” Quorum Books, 1998.

Peng, Mike W., and Anne Y. Ilinitch "Export intermediary firms: A note on export development research. Journal of International Business Studies, 29 (3), (1998), 609-620.

Peri, Giovanni and Francesco Requena, “The Trade Creation Effect of Immigrants: Evidence from the Remarkable Case of Spain,” Canadian Journal of Economics, 43(4), (2010): 1433 - 1459.

Rauch, J. E. and Casella, Alessandra. “Overcoming Informational Barriers to International Resource Allocation: Prices and Group Ties,” NBER Working Paper no. 6628, 1998.

Rauch, J. E. “Networks Versus Markets in International Trade.” Journal of International Economics_48, (1999), 735.

Rauch, J. E. and V. Trindale. "Ethnic Chinese Networks in International Trade” The Review of Economics and Statistics 84(1), (2002), 116-130.

Stock, J., J. H. Wright, and M. Yogo, “A Survey of Weak Instruments and Weak Identification in Generalized Method of Moments,” Journal of Business and Economic Statistics, 20(4), (2002): 518 - 529.

Trefler, Daniel. “The Case of the Missing Trade and Other Mysteries,” American Economic Review 85(5), (1995), 61-69.

Vezina P. L. “How Migrant Networks Facilitate Trade: Evidence from Swiss Exports,” mimeo University of Oxford., (2011).

Wagner D., Keith Head, and J. Reis. "Immigration and the Trade of provinces," Scottish Journal of Political Economy, 49(5), (2002), 507- 525.

Wei, Shang-Jin, “Intra-National Versus International Trade: How Stubborn are Nations in Global Integration?” NBER Research Working Paper no. 5531, (1996). 
Figure 1: Average Trade and Share of Professional Immigrants for 28 Largest U.S. Trading Partners over 1991 - 2000

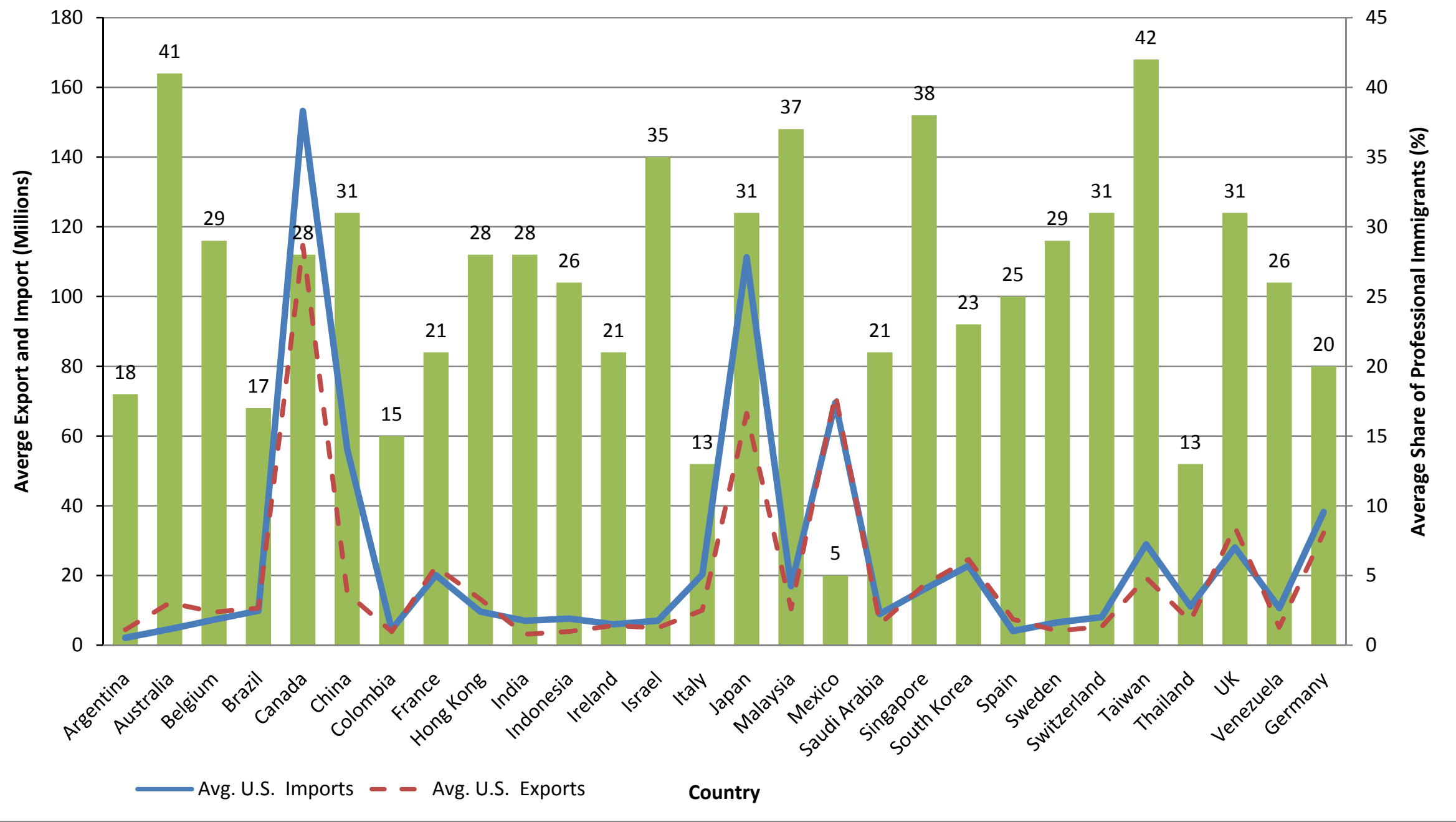


Table I: Effect of Immigrant Stock and Immigrant Occupation on Aggregate U.S. Trade

\begin{tabular}{|c|c|c|c|c|c|c|c|c|}
\hline \multirow{3}{*}{ Variables } & \multicolumn{4}{|c|}{ Log of Exports } & \multicolumn{4}{|c|}{ Log of Imports } \\
\hline & \multirow[b]{2}{*}{ (1) } & OLS & \multicolumn{2}{|c|}{ IV } & \multicolumn{2}{|l|}{ OLS } & \multicolumn{2}{|l|}{ IV } \\
\hline & & (2) & (3) & (4) & (5) & (6) & (7) & (8) \\
\hline \multirow[t]{2}{*}{$\ln \left(G N P_{u s} G N P_{j}\right)$} & $0.500 * * *$ & $0.455 * * *$ & $0.603 * * *$ & $0.564 * * *$ & $0.551 * * *$ & $0.506 * * *$ & $0.617 * * *$ & $0.455 * * *$ \\
\hline & $(0.040)$ & $(0.049)$ & $(0.051)$ & $(0.056)$ & $(0.068)$ & $(0.081)$ & $(0.083)$ & $(0.049)$ \\
\hline \multirow{2}{*}{$\ln \left(P G N P_{u s} P G N P_{j}\right)$} & $0.666^{* * *}$ & $0.661 * * *$ & $0.615 * * *$ & $0.624 * * *$ & $0.703 * * *$ & $0.704 * * *$ & $0.615^{* * *}$ & $0.661 * * *$ \\
\hline & $(0.044)$ & $(0.047)$ & $(0.044)$ & $(0.049)$ & $(0.070)$ & $(0.071)$ & $(0.071)$ & $(0.045)$ \\
\hline \multirow{2}{*}{$\ln (D I S T A N C E)$} & 0.087 & -0.068 & 0.216 & $-0.458 * * *$ & -0.082 & -0.238 & -0.410 & -0.068 \\
\hline & $(0.147)$ & $(0.124)$ & $(0.176)$ & $(0.125)$ & $(0.244)$ & $(0.207)$ & $(0.301)$ & $(0.124)$ \\
\hline \multirow{2}{*}{ ADJACENT } & $1.640 * * *$ & $1.324 * * *$ & $1.106^{* * *}$ & $0.561 * *$ & $1.430 * * *$ & $1.139 * *$ & 0.961 & $1.324 * * *$ \\
\hline & $(0.337)$ & $(0.293)$ & $(0.388)$ & $(0.292)$ & $(0.590)$ & $(0.513)$ & $(0.698)$ & $(0.293)$ \\
\hline \multirow[t]{2}{*}{ ENGLISH } & $0.301^{* *}$ & 0.096 & $0.422 * * *$ & $0.292 *$ & $0.518^{* *}$ & 0.268 & $0.617 * * *$ & 0.096 \\
\hline & $(0.118)$ & $(0.164)$ & $(0.132)$ & $(0.170)$ & $(0.200)$ & $(0.282)$ & $(0.223)$ & $(0.164)$ \\
\hline \multirow[t]{2}{*}{$\ln I M M$} & $0.323 * * *$ & $0.307 * * *$ & $0.194 * * *$ & $0.188 * * *$ & $0.331 * * *$ & $0.291 * * *$ & $0.206 * * *$ & $0.195^{* *}$ \\
\hline & $(0.048)$ & $(0.055)$ & $(0.068)$ & $(0.063)$ & $(0.068)$ & $(0.079)$ & $(0.099)$ & $(0.098)$ \\
\hline \multirow[t]{2}{*}{ ln $I M M *$ Share Professional } & & $0.002 * * *$ & & $0.002 * *$ & & $0.003^{* *}$ & & 0.001 \\
\hline & & $(0.001)$ & & $(0.001)$ & & $(0.001)$ & & $(0.001)$ \\
\hline \multirow[t]{2}{*}{ In $I M M *$ Share Services } & & 0.0003 & & $0.001 *$ & & -0.0003 & & 0.0009 \\
\hline & & $(0.001)$ & & $(0.0007)$ & & $(0.0007)$ & & $(0.0008)$ \\
\hline \multirow[t]{2}{*}{ ln $I M M *$ Share Laborers } & & 0.001 & & -0.0004 & & $0.002^{* *}$ & & -0.0008 \\
\hline & & $(0.001)$ & & $(0.001)$ & & $(0.001)$ & & $(0.001)$ \\
\hline \multirow[t]{2}{*}{ Constant } & $-23.375 * * *$ & $-19.996 * * *$ & $-23.916 * * *$ & -20.395 & $-25.711 * * *$ & $-22.310 * * *$ & $-23.310 * * *$ & $-20.977 * * *$ \\
\hline & $(1.783)$ & $(2.265)$ & $(1.749)$ & $(2.507)$ & $(2.744)$ & (3.634) & $(2.656)$ & (3.979) \\
\hline F-Statistic (p-value) & $1243(0.000)$ & $1219(0.000)$ & $1117(0.000)$ & $1055(0.000)$ & $1002(0.000)$ & $891(0.000)$ & $995(0.000)$ & $876(0.000)$ \\
\hline No. of observations & 583 & 583 & 564 & 564 & 592 & 592 & 572 & 572 \\
\hline
\end{tabular}

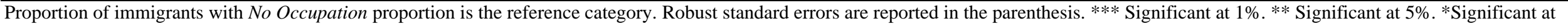
$10 \%$ 
Table II: Effect of Immigrant Stock and Immigrant Occupation on the Rauch's Reference Priced U.S. Trade

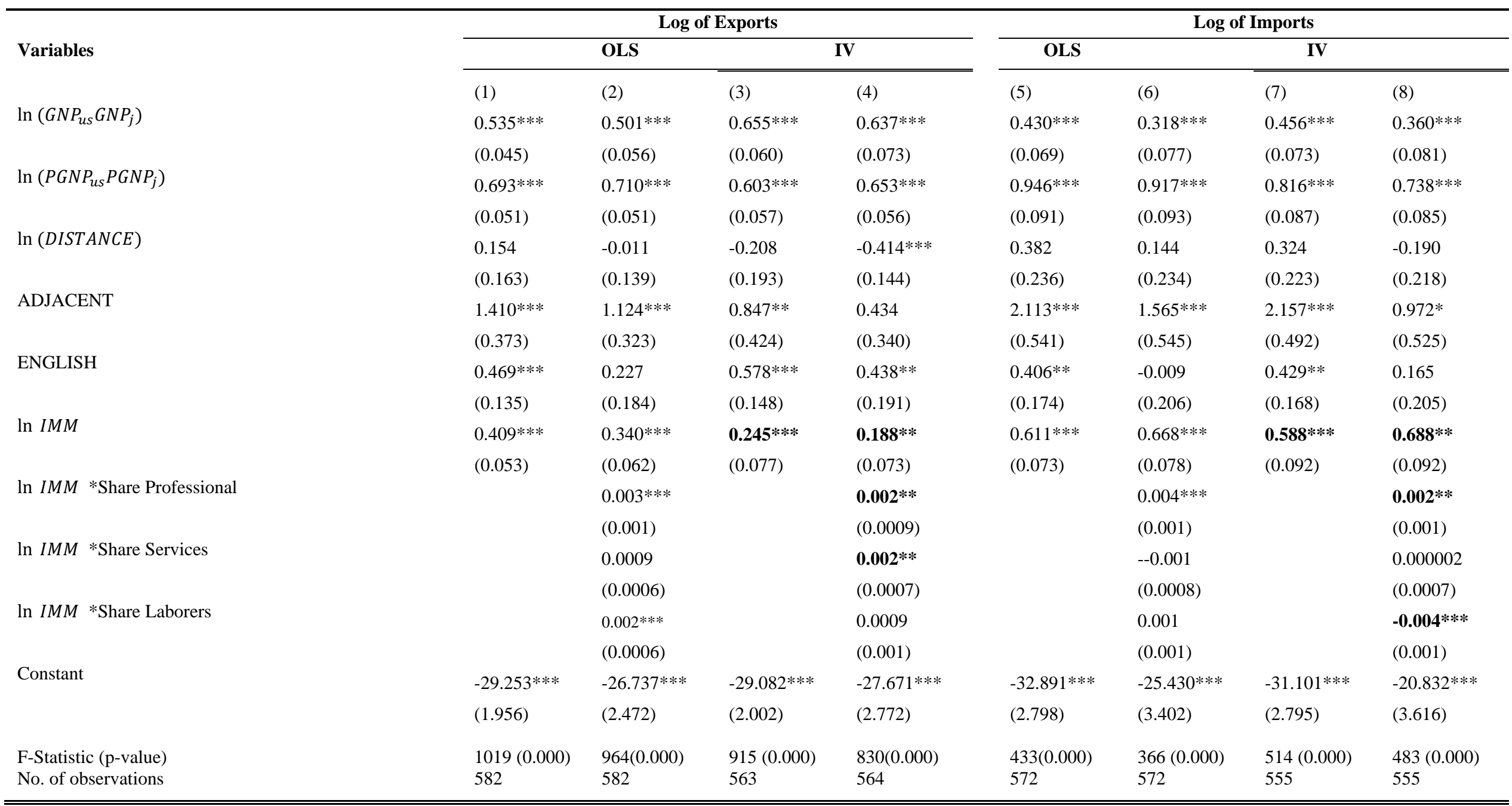

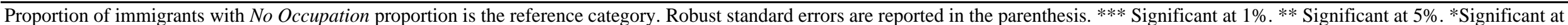
10\% 
Table III: Effect of Immigrant Population and Immigrant Occupation on the Rauch's Differentiated U.S. Trade

\begin{tabular}{|c|c|c|c|c|c|c|c|c|}
\hline \multirow{3}{*}{ Variables } & \multicolumn{4}{|c|}{ Log of Exports } & \multicolumn{4}{|c|}{ Log of Imports } \\
\hline & \multirow[b]{2}{*}{ (1) } & OLS & \multicolumn{2}{|c|}{ IV } & \multicolumn{2}{|l|}{ OLS } & \multicolumn{2}{|l|}{ IV } \\
\hline & & (2) & (3) & (4) & (5) & (6) & (7) & (8) \\
\hline $\ln \left(G N P_{u s} G N P_{j}\right)$ & $(0.041)$ & $(0.050)$ & $(0.051)$ & $(0.055)$ & $(0.067)$ & $(0.073)$ & $(0.091)$ & $(0.082)$ \\
\hline \multirow[t]{2}{*}{$\ln \left(P G N P_{u s} P G N P_{j}\right)$} & $0.754 * * *$ & $0.737 * * *$ & $0.714 * * *$ & $0.7004 * * *$ & $1.006 * * *$ & $0.980 * * *$ & $0.979 * * *$ & $0.917 * * *$ \\
\hline & $(0.050)$ & $(0.049)$ & $(0.053)$ & $(0.051)$ & $(0.075)$ & $(0.082)$ & $(0.076)$ & $(0.085)$ \\
\hline \multirow[t]{2}{*}{$\ln (D I S T A N C E)$} & 0.159 & -0.037 & -0.076 & $-0.411 * * *$ & $0.670 * * *$ & $0.353^{*}$ & $0.840 * * *$ & 0.208 \\
\hline & $(0.143)$ & (0.129) & $(0.164)$ & $(0.128)$ & $(0.220)$ & $(0.194)$ & $(0.237)$ & $(0.197)$ \\
\hline \multirow{2}{*}{ ADJACENT } & $1.931 * * *$ & $1.510 * * *$ & $1.505^{* * *}$ & $0.736^{* *}$ & $2.559 * * *$ & $1.918^{* *}$ & $2.884 * * *$ & $1.531 * * *$ \\
\hline & $(0.333)$ & $(0.307)$ & $(0.366)$ & $(0.300)$ & $(0.490)$ & $(0.448)$ & $(0.507)$ & $(0.469)$ \\
\hline \multirow{2}{*}{ ENGLISH } & 0.2009 & -0.058 & $0.311^{* *}$ & 0.126 & 0.157 & $-0.389 *$ & 0.097 & -0.359 \\
\hline & $(0.123)$ & $(0.156)$ & $(0.130)$ & (0.159) & $(0.175)$ & $(0.218)$ & $(0.186)$ & $(0.234)$ \\
\hline \multirow[t]{2}{*}{$\ln I M M$} & $0.349 * * *$ & $0.351 * * *$ & $0.248 * * *$ & $0.261 * * *$ & $0.763 * * *$ & $0.736 * * *$ & $0.821 * * *$ & $0.804 * *$ \\
\hline & $(0.049)$ & $(0.056)$ & $(0.067)$ & $(0.063)$ & $(0.067)$ & $(0.065)$ & $(0.091)$ & $(0.087)$ \\
\hline \multirow{2}{*}{ ln $I M M *$ Share Professional } & & $0.003 * * *$ & & $0.002 * * *$ & & $0.006 * * *$ & & $0.006 * * *$ \\
\hline & & $(0.0007)$ & & $(0.0007)$ & & $(0.001)$ & & $(0.001)$ \\
\hline \multirow[t]{2}{*}{ ln $I M M *$ Share Services } & & -0.00003 & & 0.0009 & & $-0.0015^{* *}$ & & -0.0007 \\
\hline & & $(0.001)$ & & $(0.0007)$ & & $(0.0007)$ & & $(0.0007)$ \\
\hline \multirow[t]{2}{*}{$\ln I M M *$ Share Laborers } & & 0.0009 & & -0.0008 & & $0.004 * * *$ & & 0.001 \\
\hline & & $(0.001)$ & & $(0.001)$ & & $(0.0008)$ & & $(0.001)$ \\
\hline \multirow[t]{2}{*}{ Constant } & $-23.989 * * *$ & $-19.164 * * *$ & $-24.563 * * *$ & $-18.912^{* * *}$ & $-44.152 * * *$ & $--35.559 * * *$ & $--43.224 * * *$ & $-31.938 * * *$ \\
\hline & (1.803) & $(2.297)$ & $(1.780)$ & $(2.470)$ & $(2.360)$ & (3.306) & $(2.284)$ & (3.748) \\
\hline F-Statistic (p-value) & $1125(0.000)$ & $1055(0.000)$ & $1054(0.000)$ & $956(0.000)$ & $859(0.000)$ & $832(0.000)$ & $988(0.000)$ & $1019(0.000)$ \\
\hline No. of observations & 582 & 583 & 563 & 563 & 585 & 585 & 565 & 565 \\
\hline
\end{tabular}

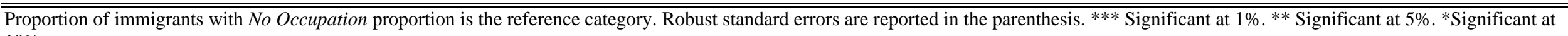
$10 \%$ 


\section{Appendix}

Table A1.- Main Findings on Average Immigrant Trade Elasticity (Network size) in the Literature for U.S. and Canada

\begin{tabular}{|c|c|c|c|}
\hline Paper & Data & Exports & Imports \\
\hline Gould (1994) & $\begin{array}{l}\text { U.S. Aggregate Trade with } 47 \text { trading partners over } \\
\text { 1970-86 }\end{array}$ & $0.02^{\mathrm{a}}$ & $0.01^{\mathrm{a}}$ \\
\hline Head and Ries (1998) & $\begin{array}{c}\text { Canadian Aggregate Trade with } 136 \text { trading } \\
\text { partners over 1980-92 }\end{array}$ & $0.13^{b}$ & $0.39^{b}$ \\
\hline Dunlevy and Hutchinson (1999) & $\begin{array}{l}\text { U.S. Aggregate and Disaggregated Trade with } 17 \\
\text { trading partners over 1870-1910 }\end{array}$ & 0.08 & 0.29 \\
\hline Wagner et al. (2002) & Canadian provinces over 1992-95 & 0.013 & 0.092 \\
\hline Herander and Saavedra (2005) & $\begin{array}{c}\text { U.S. State Exports with } 36 \text { trading partners } \\
\text { over } 1993 \text { - } 1996\end{array}$ & 0.18 & \\
\hline Bandyopadhyay at al. (2008) & $\begin{array}{l}\text { U.S. State Exports with } 29 \text { trading partners for the } \\
\text { years } 1990 \text { and } 2000\end{array}$ & $0.266^{\mathrm{C}}$ & \\
\hline
\end{tabular}

${ }^{\mathrm{a}}$ Calculated for the year 1986.

${ }^{\mathrm{b}}$ With no immigrant heterogeneity.

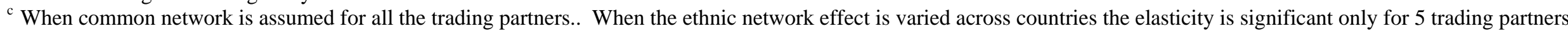
and ranges between -0.581 to 1.090 .

Some of the elasticity calculations are from Wagner et al. (2002) 
Table A2: First Stage Results for the IV Estimation

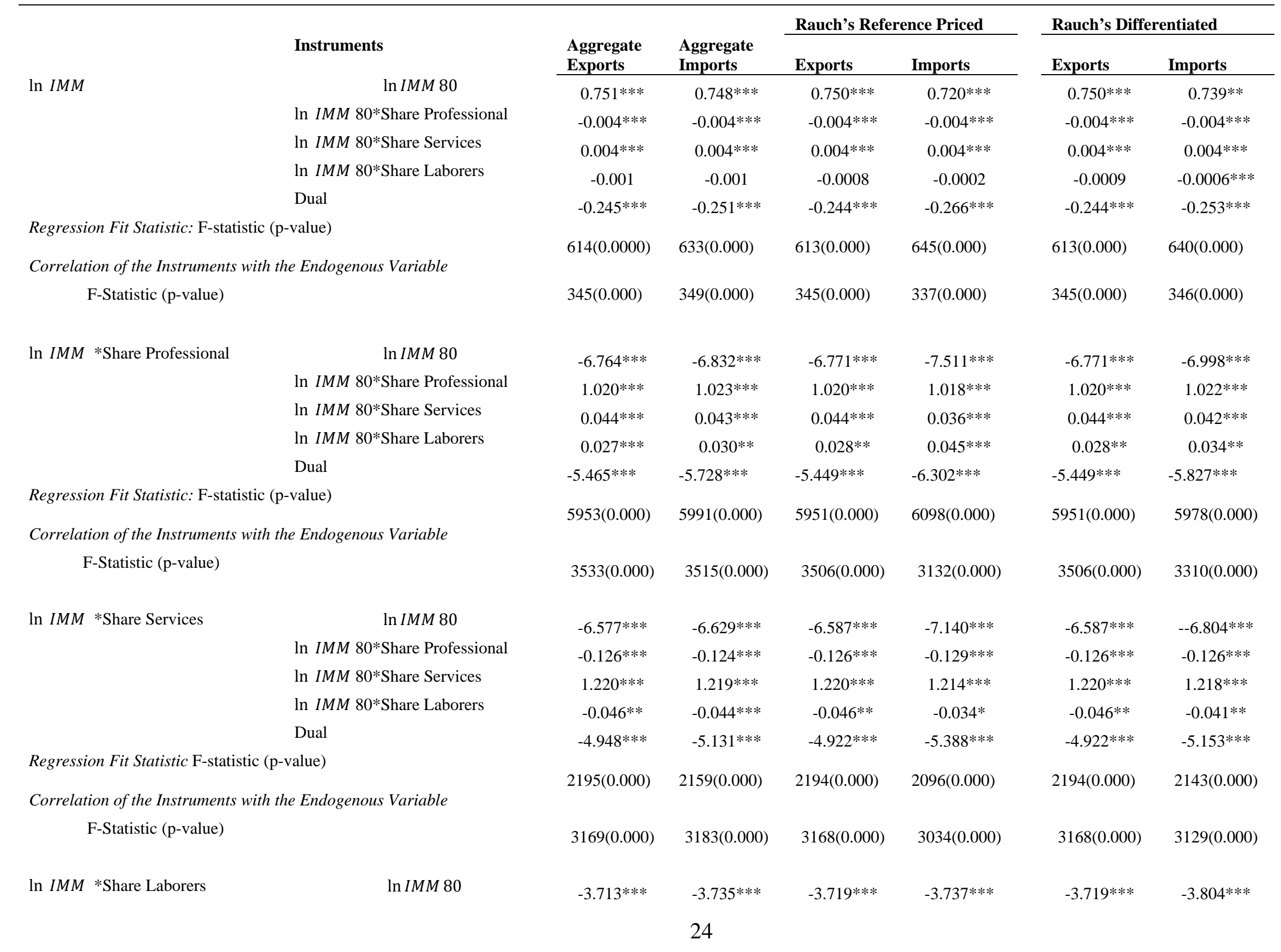




\begin{tabular}{|c|c|c|c|c|c|c|}
\hline In $I M M$ 80*Share Professional & $-0.054 * * *$ & $-0.054 * * *$ & $-0.054 * * *$ & $-0.055^{* * *}$ & $-0.054 * * *$ & $-0.055^{* * *}$ \\
\hline In $I M M 80 *$ Share Services & $0.075^{* * *}$ & $0.075^{* * *}$ & $0.075 * * *$ & $0.075^{* * *}$ & $0.0749 * * *$ & $0.075^{* * *}$ \\
\hline ln IMM 80*Share Laborers & $1.042 * * *$ & $1.043 * * *$ & $1.042 * * *$ & $1.042 * * *$ & $1.042 * * *$ & $1.044 * * *$ \\
\hline Dual & $-2.396 * * *$ & $-2.377 * * *$ & $-2.381^{* * *}$ & $-2.222 * * *$ & $-2.381^{* * *}$ & $-2.341^{* * *}$ \\
\hline e Endogenous Variable & $3907(0.000)$ & $3971(0.000)$ & $3911(0.000)$ & $3686(0.000)$ & $3911(0.000)$ & $3893(0.000)$ \\
\hline & $3851(0.000)$ & $3862(0.000)$ & $3853(0.000)$ & $3806(0.000)$ & $3853(0.000)$ & $3812(0.000)$ \\
\hline & $0.002(0.960)$ & $2.486(0.115)$ & $1.633(0.201)$ & $0.726(0.394)$ & $0.216(0.642)$ & $0.505(0.477)$ \\
\hline & 564 & 572 & 563 & 555 & 563 & 565 \\
\hline
\end{tabular}

Regression Fit Statistic F-statistic (p-value)

Correlation of the Instruments with the Endogenous Variable

$$
\text { F-Statistic (p-value) }
$$

Overidentification Test

$$
\text { Hansen J statistic (p-value) }
$$

No. of Observations

564

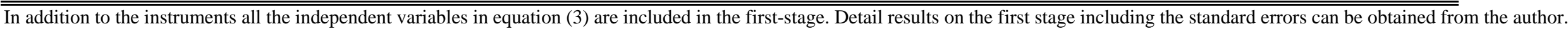
*** Significant at 1\%. ** Significant at 5\%. *Significant at $10 \%$ 
Table A3.- Average Immigrant Network Size and Distribution of Immigrant Network across Main Occupation Groups over the Period 1991 - 2000 by Country

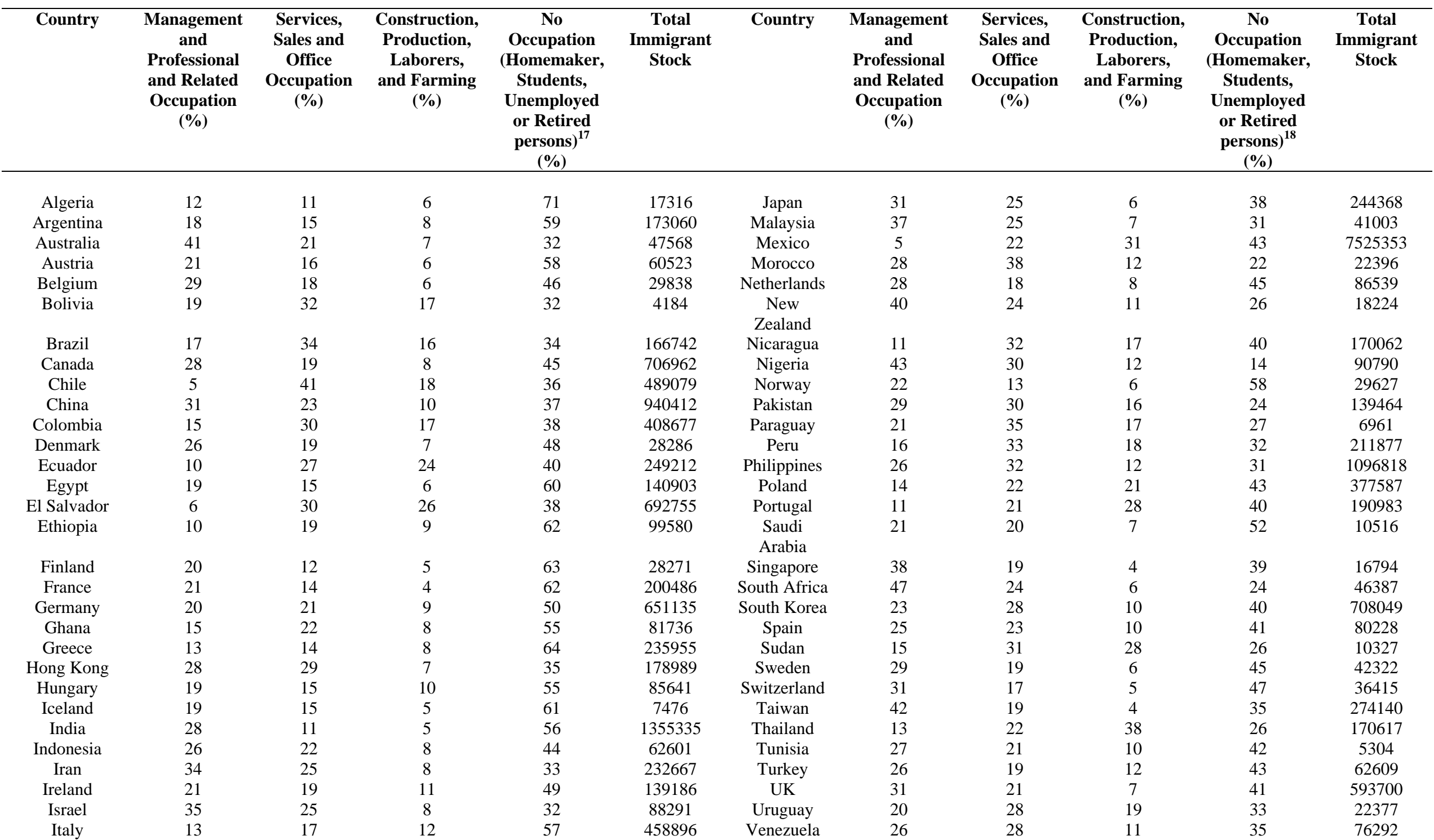

${ }^{17}$ This category in the INS data includes children. 


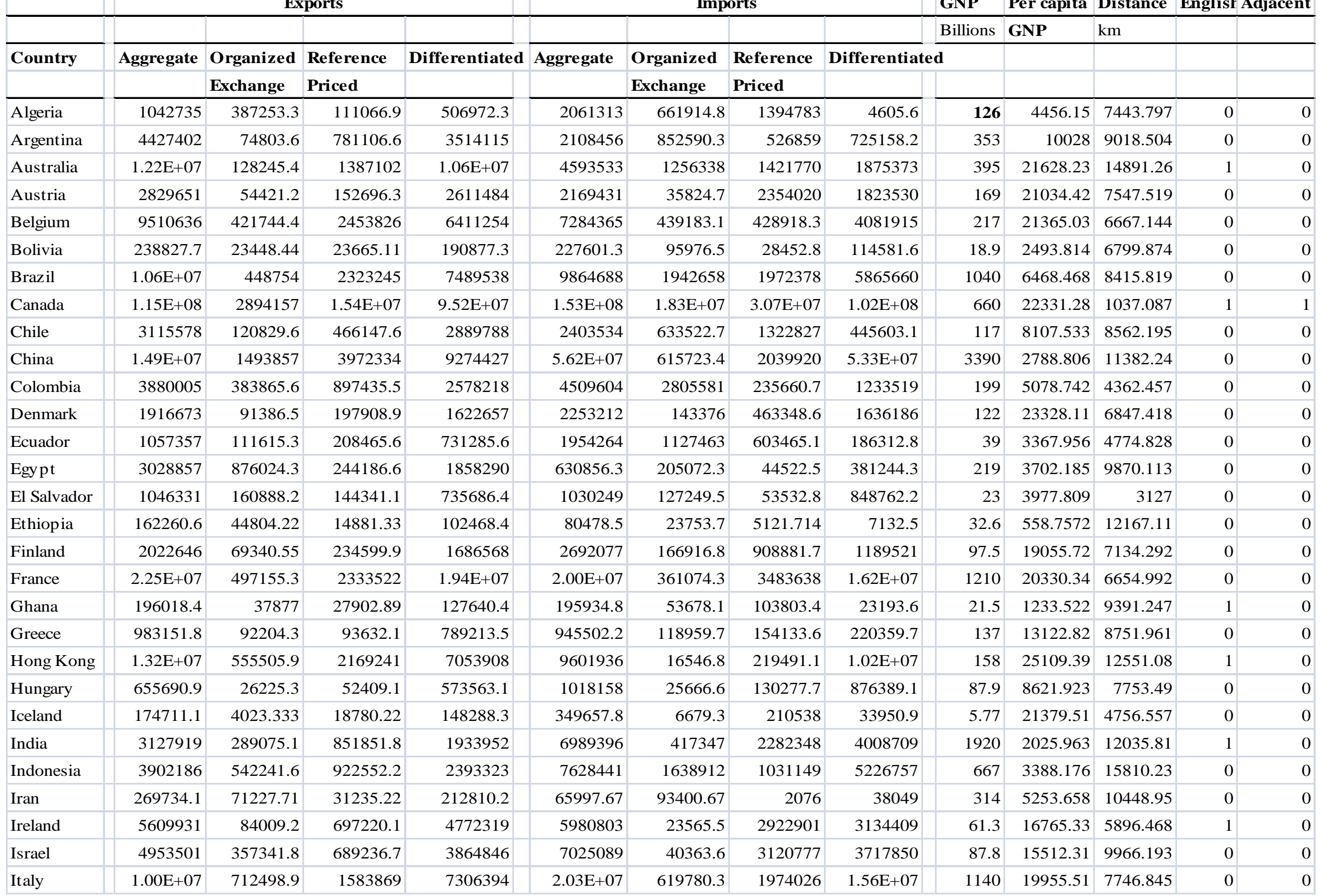




\begin{tabular}{|c|c|c|c|c|c|c|c|c|c|c|c|c|c|}
\hline Japan & $6.65 \mathrm{E}+07$ & 8947565 & $1.36 \mathrm{E}+07$ & $4.32 \mathrm{E}+07$ & $1.11 \mathrm{E}+08$ & 198898.5 & 5680585 & $1.15 \mathrm{E}+08$ & 2970 & 23616.72 & 10142.37 & 0 & 0 \\
\hline Kenya & 141550.8 & 27026.33 & 22183 & 92078.56 & 144088.1 & 29743.7 & 3919.556 & 66229 & 32.5 & 1182.772 & 12894.02 & & 0 \\
\hline Kuwait & 1115471 & 23381.4 & 105089.3 & 982587.6 & 2240875 & 1433254 & 14208 & 58091 & 41.4 & 25321.26 & 10886.55 & 0 & 0 \\
\hline Libya & 47242 & & 2002 & 68699.5 & 2659747 & & & & 30.9 & 6138.36 & 8436.447 & 0 & 0 \\
\hline Malaysia & $1.04 \mathrm{E}+07$ & 284599.8 & 855983.2 & 9235081 & $1.69 \mathrm{E}+07$ & 490036.8 & 423193 & $1.54 \mathrm{E}+07$ & 252 & 7769.425 & 14931.87 & 0 & 0 \\
\hline Mexico & $7.20 \mathrm{E}+07$ & 4700349 & $1.01 \mathrm{E}+07$ & $5.66 \mathrm{E}+07$ & $6.96 \mathrm{E}+07$ & 8467095 & 5308830 & $5.87 \mathrm{E}+07$ & 524 & 6028.844 & 2728.521 & 0 & 1 \\
\hline Morocco & 574320.6 & 206710.1 & 78351.9 & 259911.2 & 471174.4 & 16649.2 & 36443.4 & 193548.4 & 125 & 6290.162 & 6847.966 & 0 & 0 \\
\hline Netherlands & $1.37 \mathrm{E}+07$ & 987193.6 & 2293261 & $1.01 \mathrm{E}+07$ & 6685138 & 321098.3 & 1992744 & 4713516 & 260 & 19091.65 & 6616.295 & 0 & 0 \\
\hline New Zealand & 2187008 & 34435.2 & 306361.4 & 1826774 & 2639532 & 499589.1 & 654619.2 & 475802.9 & 46.1 & 12396.02 & 13462.87 & 1 & 0 \\
\hline Nicaragua & 225136 & 45587 & 26328.44 & 150720.4 & 311861 & 83913.9 & 70509.6 & 150644.6 & 24.5 & 1269.459 & 3298 & 0 & 0 \\
\hline Nigeria & 797511.6 & 200559.2 & 79212.44 & 514945.8 & 5629717 & 5705516 & 178097 & 19712.2 & 80.7 & 4897.6 & 9622.191 & 1 & 0 \\
\hline Norway & 2339818 & 75243.9 & 143083.3 & 2096608 & 3110650 & 1935073 & 698475.1 & 629077.1 & 108 & 18333.78 & 6505.226 & 0 & 0 \\
\hline Pakistan & 963687.9 & 356732.2 & 244212.5 & 390320 & 1319359 & 39240 & 142523.4 & 1199198 & 176 & 2191.239 & 12160.72 & 1 & 0 \\
\hline Paraguay & 631073.6 & 980 & 64946.11 & 564566.1 & 185023.4 & 7804.1 & 16106.7 & 26066.6 & 35.2 & 4431.892 & 8085.237 & 0 & 0 \\
\hline Peru & 1676382 & 247758.2 & 254182.1 & 1161685 & 1482301 & 732675.4 & 234087.8 & 408085.6 & 107 & 3679.941 & 6099.956 & 0 & 0 \\
\hline Philippines & 5237960 & 572103.3 & 510333.9 & 4129877 & 8248199 & 415529.9 & 193964.9 & 7950577 & 254 & 3506.498 & 13096.15 & 0 & 0 \\
\hline Poland & 1292571 & 86960.4 & 145319 & 1056182 & 675749.3 & 29741.4 & 167724.7 & 486345.1 & 237 & 7400.656 & 7515.786 & 0 & 0 \\
\hline Portugal & 1011025 & 156875.8 & 173269.3 & 613404.3 & 2348108 & 106949.6 & 106344.5 & 879893.2 & 156 & 15588.17 & 6429.297 & 0 & 0 \\
\hline Saudi Arabia & 6014930 & 360249.9 & 552508.6 & 5065789 & 8940435 & 9300673 & 504277 & 141244.2 & 266 & 14008.46 & 11267.29 & 0 & 0 \\
\hline Singapore & $1.73 \mathrm{E}+07$ & 351874.8 & 1517146 & $1.54 \mathrm{E}+07$ & $1.60 \mathrm{E}+07$ & 203320 & 655415.4 & $1.58 \mathrm{E}+07$ & 121 & 20366.68 & 15092.24 & 1 & 0 \\
\hline South Africa & 3047713 & 177417.9 & 435827.5 & 2391042 & 3002483 & 936633.4 & 1047890 & 662258.3 & 262 & 6449.91 & 13977.51 & 1 & 0 \\
\hline South Korea & $2.46 \mathrm{E}+07$ & 2970837 & 4178830 & $1.71 \mathrm{E}+07$ & $2.28 \mathrm{E}+07$ & 240905.1 & 1496043 & $2.25 \mathrm{E}+07$ & 541 & 12159.27 & 10518.28 & 0 & 0 \\
\hline Spain & 7413176 & 975092.8 & 1015369 & 5211986 & 4046428 & 387809.5 & 750347.7 & 3132861 & 670 & 16853.81 & 6733.445 & 0 & 0 \\
\hline Sudan & 42277.78 & 11553.33 & 7488.667 & 23072 & 201935.7 & 3166 & 2533.667 & 15535.38 & 28 & 893.8417 & 11176.4 & 1 & 0 \\
\hline Sweden & 4104163 & 85681.2 & 360164.8 & 3599795 & 6524063 & 174486.6 & 797166.1 & 5718027 & 164 & 19819.49 & 6885.214 & 0 & 0 \\
\hline Switzerland & 5251588 & 251523.7 & 815702.5 & 4105024 & 8028079 & 202557.3 & 1386473 & 6209942 & 191 & 26963.31 & 7056.792 & 0 & 0 \\
\hline Taiwan & $1.94 \mathrm{E}+07$ & 2210040 & 3645890 & $1.33 \mathrm{E}+07$ & $2.89 \mathrm{E}+07$ & 31348.1 & 820400.6 & $3.03 E+07$ & 115 & 2285.667 & 12003.36 & 0 & 0 \\
\hline Thailand & 6891729 & 458909 & 914401 & 5447890 & $1.11 \mathrm{E}+07$ & 519040.3 & 1640257 & 9422570 & 278 & 5554.765 & 13785.76 & 0 & 0 \\
\hline Tunisia & 340070.8 & 109044.1 & 34672.5 & 195928.6 & 81265.9 & 21025.4 & 10151.1 & 32111.4 & 88.7 & 5110.096 & 7947.622 & 0 & 0 \\
\hline Turkey & 3293275 & 715692.3 & 532642.2 & 1951411 & 2897276 & 321486 & 323086.5 & 1343006 & 489 & 8039.569 & 9129.032 & 0 & 0 \\
\hline UK & $3.39 \mathrm{E}+07$ & 799002.8 & 3477976 & $2.93 \mathrm{E}+07$ & $2.80 \mathrm{E}+07$ & 3009855 & 4073820 & $2.27 \mathrm{E}+07$ & 2040 & 19870.92 & 6359.868 & 1 & 0 \\
\hline Uruguay & 355778.3 & 8652.444 & 55726.44 & 290496.1 & 775898.8 & 66748.6 & 34820.9 & 144727.5 & 47.7 & 8211.478 & 9126.43 & 0 & 0 \\
\hline Venezuela & 5108059 & 402891.8 & 811297.5 & 3855786 & $1.07 \mathrm{E}+07$ & 9989681 & 792669.6 & 625415 & 378 & 8077.747 & 4035.429 & 0 & 0 \\
\hline Germany & $3.22 \mathrm{E}+07$ & 1239622 & 3294537 & $2.75 \mathrm{E}+07$ & $3.82 \mathrm{E}+07$ & 550830.5 & 5036970 & $3.51 \mathrm{E}+07$ & 1470 & 18098.03 & 6838.921 & 0 & 0 \\
\hline
\end{tabular}

